\title{
The Discrepancy between Art, Philosophy, Religion, and the Aesthetic
}

\author{
Dr. Abdel Elah Al-Nehar \\ Associate Prof. Dept. of English Mu'tah University \\ *Corresponding Author: Dr. Abdel Elah Al-Nehar, Associate Prof. Dept. of English Mu'tah University
}

\begin{abstract}
The aim of this paper is to shed light on the discrepancy between art, philosophy, religion, and the aesthetic. These terms are interwoven together that make the reader perplexed and puzzled to grasp each of these terms.

The paper discusses the viewpoints of well known philosophers like Kant, Hegel, Collingwood, and the viewpoints of men of letters like Emerson, Sidney, Coleridge, Wordsworth and Keats. Also the paper discusses some standpoints of theologians and the aesthetics viewpoints like Collingwood, Kant, Santayana, and Schiller respectively.

There is no space here to discuss each term mentioned above; all are discussed in detail in the forthcoming text.

Keywords: Discrepancy, Art, Philosophy, Religion, Aesthetic
\end{abstract}

\section{INTRODUCTION}

In the Middle Ages art, science, philosophy, history and practical life were all offshoots of religion, and so regarded theoretically. Nowadays, however, they are usually treated as separate universes of discourse. The most sustained attempts to chart their boundaries have been made within the Idealist tradition. Here each is assumed to be a particular mode, or phase, of Geist (the German word for both 'mind' and 'spirit'). Typical Idealist thinkers in this respect are Kant, Schiller, Hegal, Croce, Collingwood, Oakeshott and Santayana'.

The key tenet of Idealism is that reality is first and foremost mental. (Nature and the physical world are merely abstract aspects of it). That is, it belongs to consciousness, from whose contents, or possible contents, it is scarcely to be distinguished. Anything wholly transcendental -- i.e. permanently inaccessible to consciousness -- might as well, at least for a strict Hegelian, not exist. A thing exists, ultimately, only so far as it can exist for us. Emerson states in his "The Transcendentalist" that "Every materialist will be an idealist; but an idealist can never go backward to be a materiallist"

Nevertheless, for many Idealists, the phenomenal world (the world as it appears to consciousness) is shot through with intimations of transcendence. For Kant, since the transcendental is ex hypothesi inscrutable, traditional theology is impossible. The divine (which, whatever else it may be, is normally thought of as transcendental) cannot be known, 'proved', or reasoned about. At best it can be intuited from the manifest facts of ethical and aesthetic life. Emerson adds that the "idealist does not deny the sensuous fact: by no means; but he will not see that alone. He does not deny the presence of this table, this chair, and the walls of this room, but he looks at these things as the reverse side of the tapestry, as the other end, each being a sequal of a spiritual fact which nearly concerns him. This manner of looking at things transfers every object in nature from an independent and anomalous position without there, into the consciousness"3.

${ }^{1}$ Gillespie, Michael Allen. Hegel, Heidegger, and the Ground of History. The University of Chicago Press. Chicago and London, 1993, p. 86

${ }_{2}^{2}$ Selections from Ralph Waldo Emerson (The Transcendentalist), ed. Stephen E. Whicher. Houghton Mifflin Company, Boston, 1960, p. 193

${ }^{3}$ Emerson, p. 193 
Judgments in both spheres ('this is good', 'that is beautiful', etc.) possess a peculiar subjective immediacy which seems to confirm their implicit claim to objective, universal validity. The self is necessarily their focus, but their intrinsic structure is such as to point away from it, towards the transcendental. The reality of the transcendental is underwritten by the fact that the experiencing self must logically belong to it, since it cannot simultaneously be an object of its own observation.

In ethical life, according to Kant, we feel ourselves to be governed by an imperative which no naturalistic or utilitarian considerations can fully explain ${ }^{4}$. No doubt the cohesion of society, like our aggregate self-interest, is furthered by observance of the unwritten moral law, but that is not the reason, subjectively speaking, why we observe it. We observe it simply because we know we must; and that undeniable 'must', though (or perhaps because) it is inscrutable, points to a transcendent source. A command cannot issue from nowhere.

Aesthetic judgment similarly legislates for all observers. A thing can be pleasing, but it cannot be beautiful. The beautiful is not independent of the observer's subjectivity, since a thing's beauty, though objective, must be subjectively experienced. It cannot simply be taken on authority or accepted as a piece of information, as Keats confirms in his "ode on a Grecian Urn", "Beauty is truth, truth beauty, that is all ye know on earth, and all ye need to know".

It is, however, independent of the observer's self-interest. This makes it apprehensible only by those, who have the capacity to suspend their self-interest. On the other hand, it is also independent of the observer's moral interests and enthusiasms. It is not its goodness which makes a thing beautiful, but its appearance of 'free' or self-governed purposiveness. (Not, be it noted, its appearance of serving some extraneous purpose. The latter is the principle behind the so-called 'functionalist' aesthetic, where beauty is not 'free', but dependent on function) ${ }^{\mathbf{5}}$.

Kant was notoriously indifferent to art, and has little to say about it, since he invariably regards its beauty as inferior to that of nature. But what he says about the relation of the aesthetic and the moral to the transcendental is clearly suggestive in respect of any joint consideration of art and religion, particularly in the case of his remarks on the sublime. Kant's response to the sublime in nature and in art, so far as "art reflects nature and prefigures the religious attitude" ${ }^{6}$. It consists in the awareness of an awesome limitlessness and unbounded power, but natural fear of such a power is qualified by a sense of righteousness and innocence when confronted by it.

In this respect the awe provoked by the sublime differs from the superstitious, self-abasing terror of the savage. The civilized man's fortitude and self-respect -- i.e. his own sublimity of character -- at once enable him to triumph over a threatening nature (or his terror in the face of it) and reconcile him with it, so that he not only participates in its power, but also gathers from it the intimation of an underlying, and ultimately benevolent, divinity ${ }^{7}$.

Schiller's account of the sublime, as of the aesthetic generally, has much in common with Kant's. Hegel's aesthetics, however, like his metaphysics, are different ${ }^{8}$. They are art-rather than naturecentred. Art is superior to nature as a vehicle of the divine, because, like the Absolute Mind (or Idea) of which the universe as a whole consists, and unlike nature, it too is self-conscious, or a product of self-consciousness. In his "science of the Experience of Consciousness", Hegel considers consciousness primarily as individual consciousness, which participates in the general but which is and remains the consciousness of an I, i.e., the relationship of being and knowing in and through the I. The experience of consciousness is, on one hand, the actual historical development of the individual I as the process of the coming to know itself and, on the other hand, the development of the twofold of being and knowing, that is, of the various forms of historical consciousness and hence of the world and knowledge as they appear in and through consciousness 9

\footnotetext{
${ }^{4}$ Kant, Immanuel. The Critique of Judgment, trans. J.C. Meredith. Oxford: Clarendon Press, 1969, p. 94 .

5 Schiller, Friedrich Von: On the Aesthetic Education of Man, ed. And trans. E. M. Wilkinson. Oxford: Clarendon Press, 1967, p. 102

${ }^{6}$ Kant, p. 112.

${ }^{7}$ Schiller, p. 116.

${ }^{8}$ Hegel, Georg Wilhelm Friedrich, Phenomenology of Spirit, trans. By Arnold V. Miller, Oxford: Oxford University Press, 1977, p. 57.

${ }^{9}$ Mechael Allen Gillespie Hegel's "Science of the Phenomenology of Spririt" Quoted in Hegel, Heidegger, and the Ground of History, p. 61.
} 
The divine, however, is not transcendent, since there is no transcendence, Hegel's 'God', therefore, is more or less a figure of speech, being simply the immanent Absolute risen to self-consciousness in the world which it has itself created or 'posited'. A prime medium through which it rises to selfconsciousness is art, defined as 'the sensuous embodiment of the Idea ${ }^{\mathbf{1 0}}$.

In primitive or 'symbolic' art the Absolute fails to achieve full articulation, being overwhelmed by the 'crassness' (as Hegel calls it) of the sensuous or natural world. This is because man, or incarnate Mind, is yet undeveloped, and is hence still too deeply enmeshed in that world. At the other extreme, in modern or 'romantic' art like Blake's and Keats', form has been outstripped by content. Mind is now so self-aware that representations of nature (which is not self-aware) are inadequate fully to embody it ${ }^{11}$. Art has finally been superseded by philosophy (most notably by Hegel's own), in which alone the Absolute is completely realized, and of which even religion is a mere shadow. Only in 'classical' art, epitomised by Graeco-Roman sculpture, are form and content wholly in balance, since only then was the evolving Idea precisely matched to the natural forms available for its representation, i.e. the human body, used to depict the gods, as well as the sculptures and statues of the ancient pharaohs of Egypt found in their pyramids and tombs.

Hegel's aesthetics, like his ethics, are a branch of his metaphysics. The Beautiful is essentially an 'appearance' of the True, of ultimate reality. The aesthetic Ideal is the Idea in sensible form. If it be asked why the Real should manifest itself in beauty, the reason lies in its essential organic harmony, or unity in diversity, which is also the principle of the beautiful ${ }^{\mathbf{1 2}}$.

The earlier Collingwood, like Hegel, sees religion as a more 'advanced' phase of spirit than art. For religion, though defective, deliberately aims at truth, while art (like primitive man) is indifferent to truth, making no distinction between fact and imagination. Religion is the prototype of science, history, and philosophy. Other thinkers (including Santayana and Collingwood) have seen art as superior to religion, precisely because, in its purest or most mature form, it actively asserts nothing ${ }^{\mathbf{1 3}}$. 'The poet nothing affirmeth', said Sir Philip Sidney, 'and therefore never lieth' ${ }^{\mathbf{1 4}}$. The idea that art (or the highest art) is essentially non-declarative points in two directions. On the one hand it leads to aestheticism, the view, central to the so-called Aesthetic Movement (e.g. Pater, Whistler, Wilde), to Bloomsbury aesthetics (e.g. Fry, Bell), and to Oakeshott, that aesthetic experience, and thus art, is not like anything else. I see there is no need and space to discuss the aestheticists alluded to above separately or connectively.

On the other hand, art's non-declarative character is taken by some (mostly critics, such as Matthew Arnold and F. R. Leavis, rather than philosophers) merely to indicate that, unlike religion (or at least, dogmatic religion), it recognises the limits of the sayable. Nevertheless, what cannot be said can still be suggested; and art's suggestiveness, for all that its medium is fiction, is actually truer to the complexities of experience than the cut-and-dried factual claims of religion or philosophy.

A tacit presupposition of this view (which is essentially a secular Kantianism, disengaged from any explicit metaphysical theory) is that all art, even non-realist art, is in some sense representational. (Socalled 'expressive' art may be thought to represent inner, 'subjective' experience, which eludes one-toone pictorial or linguistic articulation). Art points beyond itself to a reality apprehensible by no other means. It elicits meaning and coherence from experience. Art reconciles us to life by exposing some of its mysteries as superficial, and persuading us humbly to accept the rest. Kant demonstrated in his "Transcendental Aesthetic", "that all that we experience has no grounded existence outside of our own thought; that we do not perceive or experience the things in themselves but only that which appears within the forms of our consciousness-within space and time ${ }^{15}$. In short, art does what religion offers

${ }^{10}$ R. G., Collingwood, The Principles of Art, Clarendon Press, 1938, reprinted 1995, p. 72.

${ }^{11}$ See Coleridge's. Biographia Literaria, Chs. 4, 13.

12 G. W. F., Hegel. Hegel's Introduction to Aesthetics. Trans. T. M. Knox, ed. C. Karelis. Oxford: Clarendon Press, 1979, p. 32

${ }^{13}$ R. G. Collingwood, Speculum Mentis: or the map of knowledge, Oxford: Clarendon Press, 1924, reprinted, 1952, 65, 84, p. 102

${ }^{14}$ Sir Philip Sidney, "The Defence of Poesy", Norton Anthology of English Literature, V. I, Norton and Company: New York, London, p. 504-505

${ }^{15}$ Yirmiahu, Yovel, Kant and the Philosophy of History. Princeton University Press, 1980, p. 132 
to do, only better, because more honestly. Religion achieves symbolic 'truth' precisely by forswearing any claim to literal veracity.

What mentioned above raises the question as to whether religious art can be called art at all, unless religion itself is somehow to be regarded as an imperfect form of art. Clearly, on the Idealist view, both art and religion endeavour, by imaginative means, to discover structure and meaning in the cosmos. The difference is that art knows itself to be fictional (at least in form), whereas religion claims to be true. It demands active belief, where art demands at most Coleridge's 'willing suspension of disbelief ${ }^{16}$.

Art which invites literal or near-literal belief is fantasy-art (what Plato supposed most art to be). Its aim is to excite pleasurable emotions by constructing, and sustaining, an illusory world more submissive to the subject's self-indulgent desires than the real one can be. Accordingly it will usually employ more surface verisimilitude, and less obvious stylization, than art which has no such extraneous purpose, or whose purpose is simply to focus attention on the object for its own sake.

Hence there arises the paradox that fantasy-art often seems more 'real' than what Collingwood called 'art proper', or even than nature. An obvious example is pornography, which has come overwhelmingly to rely on photographic images. For a photograph seems to present the object directly, rather than depict it; to be not art, but fact. It thus exacts a minimum of imaginative effort from the spectator.

Collingwood stigmatised pornography as typical of 'amusement art', while regarding religious art as 'magical art'. Amusement art excites emotions simply in order that we may enjoy the sensation of having them without the responsibilities involved in acting upon them. It is, in Collingwood's view, a substitute for action ${ }^{17}$.

This conviction is shared, incidentally, by many who defend pornography as harmless, because supposedly cathartic. The question is not usually addressed as to whether the emotions concerned would stand in need of catharsis if they had not first been stimulated to an unnatural degree; nor whether, since the whole point of pornography is to obliterate the distinction between fantasy and reality, the user can be relied upon to discharge them solely in fantasy; nor whether, even if he could, his craving for fantasy ought to be indulged.

These reservations, of course, could apply equally to sentimental or any other amusement art. The impulse might legitimately be satisfied so long as its being so did not thwart the satisfaction of 'superior' impulses. Ignoring the question as to what 'superior' might mean, however, it may be felt in general that amusement art is tolerable or even valuable when we understand it to be such, and is therefore in no danger of being mastered by our fantasy, i.e. of mistaking it for reality. But clearly we have to do here not with fantasy in a pejorative or debilitating sense, rather with something like play (a category central to Schiller's aesthetics). Play may be considered either as a necessary liberation from the serious business of life, or as a rehearsal for it. In the first capacity it recalls the aestheticist view of art, in the second the Leavis view, of art as a means of grasping and mastering a complex reality, which will include the appropriate emotions ${ }^{18}$. But either option must render dubious the distinction between amusement art and 'art proper'. The real distinction is between 'art proper' and fantasy-art as discusses above.

Magical art stimulates emotions (martial, patriotic, revolutionary, religious, acquisitive, moral, etc.) with a view to their being discharged in the appropriate actions. Its value therefore will depend entirely on that of the ends it serves. The sole aesthetic criterion, if it can truly be called aesthetic, will be technical or pragmatic, concerning the efficiency with which a given art-work stimulates the required emotion. Beauty might conceivably do this (though not on Kant's view), but will otherwise be incidental like Keats' beauty ${ }^{\mathbf{1 9}}$. For crudity, either of execution, or of the emotion demanded, will

\footnotetext{
${ }^{16}$ S. T. Coleridge, Biographia Literaria, Ch. 4.

${ }^{17}$ Collingwood, p. 115

${ }^{18}$ Rene Wellek, Leavis, F. R., Literary Criticism and Philosophy. New York: New York University Press, 1984, p. 116

${ }^{19}$ See John Keats "Ode on a Grecian Urn".
} 
not matter so long as the emotion is, in fact, evoked and acted upon. A vulgar advertisement may sell a product better than a sophisticated one. A sentimental religious print may conduce to piety as effectively as an artistic masterpiece, and more. From a religious standpoint, as from any other of a primarily purposive character, 'good' art, or 'art proper', is superfluous, except as a lexicon of proven techniques of emotional stimulation.

Indeed, in and for itself, 'art proper' might even be harmful. The object of religion is to open the mind to the possibility of transcendent things, and thereafter to close it. In the religious view the complexities of experience, transcendent or otherwise, to which 'art proper' exposes us are at best irrelevant, and at worst a return to the chaos and doubt from which, in virtue of its affirmative or even dogmatic character, religion rescues us.

It might be said, nevertheless, that 'art proper' is itself insufficiently distinguishable, except on pure aestheticist premises, from magical art. Certainly nineteenth-century realists such as George Eliot, Trollope and Tolstoy claimed to be writing with a moral purpose, revealing the hidden order of things, and extending human sympathies. How much difference is there between an art which professes (and achieves) such aims, and explicitly didactic (i.e. magical) art?

The answer might be that whatever the authors themselves may have claimed, and whatever moral effects their work actually had, what made it 'art proper' was the fact that in practice it did not subordinate the immediate aesthetic aim (truth to the object, or fidelity to the integrity of the artistic creation as such) to any prior goal, moral or otherwise. This patient refusal to jump to conclusions, or to bend the artistic process into premature conformity with them, would itself constitute a moral phenomenon and a moral example.

Science and history present parallel cases. How far religion also does so -- and here obvious political analogies suggest themselves -- will depend on whether we see religion primarily as a 'world-open' receptivity to the transcendent, or as a 'world-closed' claim finally to have captured it in doctrine. If the first, how is religion to be distinguished from art, or from its supposed effects? Those are questions which can be answered neither simply, nor here.

\section{REFERENCES}

[1] Coleridge, S. T.: Biographia Literaria, Oxford University Press, 1976.

[2] Collingwood, R. G.: Speculum Mentis: or the Map of Knowledge. Oxford: Clarendon Press, 1924, repr. 1988.

[3] Croce, Benedetto: Aesthetic.trans. D. Ainslie, London: MacMillian, 1922, repr. 1978.

[4] Durant, Will: The Story of Philosophy. A Touchstone Book Published by Simon and Schuster. New York, 1961.

[5] Hegel. G. W. F.: Hegel's Introduction to Aesthetics. Trans. J. C. Meredith. Oxford:Clarendon Press, 1969.

[6] Phenomenology of Spirit.trans. Arnold V. Miller. Oxford University Press, 1977.

[7] Gillespie. Michael Allen. Hegel, Heidegger, and the Ground of History. The University of Chicogo Press. Chicago and London, 1993.

[8] Kant, Immanuel: The Critique of Judgment. Trans. J. C. Meredith: Oxford Clarendon Press, 1969.

[9] Keats, John. "Ode on a Grecian Urn".

[10] Leavis, F. R., and Wellek, Rene: "Literary Criticism and Philosophy" in Scrutiny, Vol. V, No. 4 and Vol. VI, Nos. 1, 2, reprinted in Eric Bentley, ed., The Importance of Scrutiny. New York: New York University Press, 1984.

[11] Santayana, George: The Life of Reason. London: Constable, 1922, repr. 1972.

[12] Schiller, Friedrich Von: On the Aesthetic Education of Man. Ed. And trans. E. M. Wilkinson. Oxford: Clarendon Press, 1977.

[13] Naive and Sentimental Poetry and on the Sublime. Trans. J. A. Elias. New York: Frederick Ungar, 1976.

[14] Scruton, Roger: The Philosopher on Dover Beach. Manchester: Carcanet, 1990.

[15] Sir Philip Sidney: "The Defence of Poesy" in Norton Anthology of English Literature, V. I., New York and London, 1986. 
[16] Stephen, E. Whicher. Ed. Selections from Ralph Waldo Emerson. (The Transcendentalist). Houghton Mifflin Company, Boston, 1960.

\section{AUTHOR'S BIOGRAPHY}

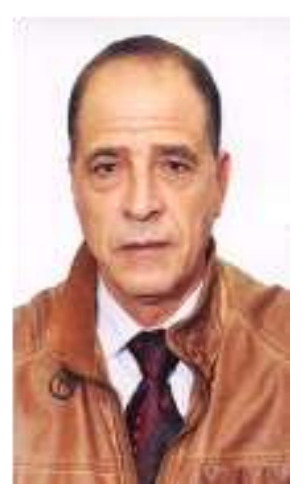

Dr. Abedel Elah Hussain Alnahar, is a Teacher Associate Prof at the University of Mutah - Jordan, Department of English Language and Literature. He Holds a PHD in English Literature from the University of Glasgow, 1991, UK. His research interest and study field English literature in general, and that is written in English language besides other branches of art and philosophy.

Citation: Dr. Abdel Elah Al-Nehar. " The Discrepancy between Art, Philosophy, Religion, and the Aesthetic." International Journal on Studies in English Language and Literature (IJSELL), vol 5, no. 10, 2017, pp. 1-6. doi:http://dx.doi.org/10.20431/2347-3134.0510001.

Copyright: (C) 2017 Authors. This is an open-access article distributed under the terms of the Creative Commons Attribution License, which permits unrestricted use, distribution, and reproduction in any medium, provided the original author and source are credited. 